\title{
Is it possible to share tacit knowledge using information and communication technology tools?
}

Information and communication technology tools

\author{
Delio Ignacio Castaneda
}

Department of Administration, Pontificia Universidad Javeriana, Bogota, Colombia, and

Paul Toulson

Received 23 July 2020 Revised 14 September 2020 Accepted 12 October 2020

\author{
Massey University, Auckland, New Zealand
}

\begin{abstract}
Purpose - This study aims to determine whether it is possible to use information and communication technology (ICT) tools to share tacit knowledge. Few studies have considered this subject, and they have reported both the ineffectiveness and effectiveness of ICT tools for sharing tacit knowledge.

Design/methodology/approach - In this study, the participants comprised 217 knowledge workers from New Zealand and researchers who attended a knowledge management conference in the UK. In all, 59\% of the sample was men and $41 \%$ women. The research model compared the scores of knowledge workers in two categories of ICT, those that allow dialogue and those that do not, in relation to knowledge sharing in organizations. The instrument used a Likert scale with five levels of response.

Findings - It was found that not all ICT technologies let tacit knowledge to be shared, but those ICT that facilitate dialogue, for example, text messaging and video conferences. Emails did not facilitate the exchange of tacit knowledge.

Research limitations/implications - It is suggested to replicate the study with different countries to evaluate the role of culture in the communication of tacit knowledge.

Practical implications - An implication for practitioners based on this study is that email should not be the preferred mode for transferring knowledge between an organization and their workers. This mode is adequate for the exchange of explicit knowledge, but it has a limited capacity for transferring tacit knowledge. Thus, organizations may increase the use of audio and video tools to transfer electronically tacit knowledge. Interaction or socialization may facilitate the understanding and internalization of tacit knowledge by workers.

Originality/value - This study contributed to understand the reason for contradictory results from previous research. ICT tools are effective to share tacit knowledge when they facilitate dialogue. Results also support practitioners about how to obtain more effective exchange of tacit knowledge in organizations.
\end{abstract}

Keywords Knowledge sharing, Organizations, Tacit knowledge, Knowledge management, Communication, ICT tools

Paper type Research paper

(C) Delio Ignacio Castaneda and Paul Toulson. Published by Emerald Publishing Limited. This article is published under the Creative Commons Attribution (CC BY 4.0) licence. Anyone may reproduce, distribute, translate and create derivative works of this article (for both commercial and noncommercial purposes), subject to full attribution to the original publication and authors. The full terms of this licence may be seen at http://creativecommons.org/licences/by/4.0/legalcode

Global Knowledge, Memory and Communication Vol. 70 No. 8/9, 2021 pp. $673-683$ pp. 673-683
Emerald Publishing Limited 2514-9342 DOI 10.1108/GKMC-07-2020-0102 
GKMC

$70,8 / 9$

674

\section{Introduction}

Knowledge sharing by employees within organizations has been investigated in behavioral studies in the area of knowledge management (Earl, 2001; Dingsoyr et al., 2009). Knowledge management can be defined as a systematic and integrated strategy that develops, transfer, stores and implement knowledge (Richter et al., 2019). Knowledge management involves the creation, acquisition, documentation, storage, electronic exchange, face to face interaction, application and reuse of knowledge (Castaneda et al., 2018). Knowledge management is driven by the flow of knowledge in an organization (Jennex et al., 2019) and focuses on creating organizational competitive advantage (Ngulube, 2019).

There are different models of knowledge management that contribute to understand organizational readiness based on knowledge. One of these is the Jennex Olfman Success Model (Jennex and Olfman, 2006). This model in the original version is an adaptation of the DeLone and McLean $(1992,2003)$ work. The model contemplates the following dimensions: system quality, knowledge quality, intent to use/perceived benefit, user satisfaction and net benefits. In the model, technological resources are part of the system quality and affect the knowledge management level and form. Technological resources define the capability of organizations to develop knowledge management infrastructure and systems. In 2020, Jennex proposed to include some variables in the model like collaborative technologies and social media. This model enlightens our research, where it was investigated the knowledge sharing process, a part of the knowledge management level, by focusing on whether it is possible to use information and communication technology (ICT) tools to share tacit knowledge.

Knowledge sharing is gaining increasing recognition because is a critical factor for the success of organizations (Suppiah and Singh-Sandhu, 2011) and a predictor of innovations (Castaneda and Cuellar, 2020). Despite a general assumption that knowledge sharing among employees is vital for achieving a competitive advantage, only limited evidence has been provided to support it (Crhová and Matosková, 2019). In particular, there are few studies and there are conflicting reports of the ineffectiveness of ICT tools for sharing tacit knowledge (Abadi et al., 2009) as well as their effectiveness (Razmerita et al., 2014). The debate about the effectiveness of ICT tools as facilitators of tacit knowledge sharing suggests that there is currently a gap in our understanding of knowledge management (Panahi et al., 2016). In this sense, the purpose of this research was to evaluate the effectiveness of ICT tools to share tacit knowledge.

\section{Knowledge sharing}

There are several definitions of the concept of knowledge sharing. Helmstadter (2003) defined the concept as the interaction between human actors where the raw material is knowledge. Gibbert and Krause (2002) defined knowledge sharing as the desire of a collaborator in an organization to give others the knowledge that he or she has created or acquired. According to Ipe and Wagner (2008), knowledge sharing is the act of making their knowledge available to others. This is a frequent behavior in informal networks (Issac and Thomas, 2020). In a specific sense, knowledge sharing is also a process that involves the transfer of experience and organizational knowledge to facilitate business development via communication channels between individuals (Oyemomi et al., 2016).

Knowledge sharing is critical for both the creation and application of organizational knowledge (Hendriks, 2004; Huysman and De Wit, 2002), which are essential processes that allow organizations to achieve their goals. Serenko and Bontis (2016) concluded that knowledge sharing is one of the most important research topics in management. The complexity of knowledge sharing is related to the fact that it is not an automatic and unconditional behavior (Wah et al., 2005), but instead it is highly dependent on a variety of 
human factors such as beliefs and perceptions (Castaneda and Toulson, 2013; Dougherty, 1999; Helmstadter, 2003; Lagerstrom and Andersson, 2003; Scarbrough and Carter, 2000).

Many studies have contributed to our understanding of knowledge sharing in terms of why and how it occurs (Steward, 2008; Wang and Noe, 2010). The main research area related to knowledge sharing comprises studies of psychosocial variables and the organizational conditions that might explain it. For example, relationships have been found between knowledge sharing behavior and attitudes toward sharing knowledge (Bock and Kim, 2002), subjective norms (Castaneda, 2015), self-efficacy (Castaneda et al., 2016), motivation (Takpuie and Tanner, 2016), trust (Rutten et al., 2016), types of leadership (Duran and Castaneda, 2015), task conflicts (Hewitt et al., 2020) and the organizational climate (Villamizar and Castaneda, 2014). Despite the large amount of interest in knowledge sharing, few studies have investigated whether the effectiveness of knowledge sharing depends on the type of knowledge and the tools that people use to share knowledge.

\section{Types of knowledge}

The classification of the existing types of knowledge is usually based on the system proposed by the philosopher Michael Polanyi (1958), who stated that the two types of knowledge are tacit and explicit. Thus, knowledge sharing can be defined as a process where people exchange tacit and explicit knowledge (Nonaka, 2007).

Tacit knowledge is characterized by the experience, expertise and skills of an individual, which are difficult to describe with language (Haldin-Herrgard, 2000), and thus to document and store. Some other features of tacit knowledge are that it is unobservable, difficult to teach and encode, and hard to separate from the context where it exists (McLever et al., 2013). Tacit knowledge is present in insights, hunches, intuition, ideals, and values (Nonaka and Takeuchi, 1995). Tacit knowledge includes technical know-how and cultural values (Eden and Spender, 1998), mental models, and beliefs (Meso and Smith, 2000).

Explicit knowledge is structured knowledge, which is easy to describe, document, store, and transfer electronically. Explicit knowledge is characterized as being formally codified using a system of symbols (Nonaka and Takeuchi, 1995). Examples of explicit knowledge are manuals, procedures, processes, regulations, patents, formulas, articles and technical papers.

\section{ICT tools and sharing tacit knowledge}

Knowledge flows highlights the mechanism for sharing the knowledge requirements (Smuts et al., 2017). At present, organizations need tools to facilitate the sharing of tacit and explicit knowledge (Kunzel et al., 2019; van den Hooff and Huysman, 2009). These tools may be those that use ICT as a channel to share knowledge and those that do not. The ICT channel includes both hardware and software resources (Leonard-Barton, 1995). These knowledgesharing tools allow users to work with contents that are packaged, such as digital files for manuals or procedures, as well as wikis, blogs, and platforms that allow the users to collaborate by knowledge sharing (Berners-Lee et al., 2006). However, other studies such as that by Johanessen et al. (2001) concluded that is not possible to share tacit knowledge using ICT tools. The acceptance of technology for knowledge sharing is directly related to how people view the usefulness of technology for supporting their job performance, without having to make extra effort (Abdelrahman et al., 2016). For instance, knowledge sharing was shown to be positively related with technological innovation (Kunzel et al., 2019).

Falconer (2006) proposed that some tools based on ICT, such as social media, can be used to share both tacit and explicit knowledge. However, a limitation of tacit knowledge is whether this knowledge can be shared through the medium of oral language. Hence, Flanagin (2002) suggested that given its unstructured nature, tacit knowledge is limited and sometimes
Information and communication technology tools

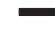


GKMC $70,8 / 9$ impossible to share. Panahi et al. (2013) proposed that ICT tools can support real-time synchronous communication in the forms of chatting, video, and text-based conferencing.

Tools based on ICT have traditionally been used to share explicit knowledge, but the results of previous studies are in conflict regarding the effectiveness of ICT tools for sharing tacit knowledge (Panahi et al., 2013). Studies of this subject are not exhaustive but some reports suggest that ICT tools are ineffective for sharing tacit knowledge (Abadi et al., 2009; Spraggon and Bodolica, 2017), whereas others have demonstrated their effectiveness (Razmerita et al., 2014; Salleh et al., 2013). Mitri (2003) proposed that in order for ICT to be effective at sharing knowledge, these tools must operate in real time, as well as being interactive and enabling the fostering of collaboration. Razmerita et al. (2016) also suggested that factors related to the success of knowledge sharing include the friendliness of electronic platforms and the training that collaborators receive in their use. Nakano et al. (2013) found that the sharing of tacit knowledge is facilitated by an engaging environment supported by shared language.

Previous studies based on interviews indicated that socialization, which is defined as talking with colleagues, is an effective tool for sharing tacit knowledge. Thus, tools based on ICT may be effective for sharing tacit knowledge when the knowledge is only exchanged orally. Del Giudice and Della Peruta (2016) reported that there is little evidence for the direct impact of ICT tools on the exchange of tacit knowledge, and they suggested that further research is required to explore how different types of ICT tools impact knowledge-sharing behavior. Online forums and chat rooms may facilitate tacit knowledge sharing, and according to Reamy (2002), storytelling is the best way to transfer tacit knowledge. Spraggon and Bodolica (2017) also suggested that social ludic activities such as games may aid knowledge transfer.

Considering previous research and the empirical gap reported in previous studies, we may ask the question: Are ICT tools effective for sharing tacit knowledge? A detailed analysis of previous studies suggests that the answer depends on the type of tacit knowledge that is shared, in particular whether or not an ICT allows dialogue.

\section{Research methods}

In this study, the participants comprised 217 knowledge workers from New Zealand and researchers who attended a knowledge management conference in the UK. In the second case, the countries with the largest samples were: the UK, Spain, Italy and Portugal; 59\% of the total sample was men and $41 \%$ women. Drucker (1999) popularized the concept of knowledge workers in order to distinguish them from manual workers. According to Drucker (1999), a knowledge worker performs tasks that require abstract thinking and the flexible application of knowledge. Autor et al. (2003) identified expert thinking, complex communication, and cognitive routines as the predominant features when describing the requirements for a knowledge worker.

The research model compares the scores of knowledge workers in two categories of ICT, those that allow dialogue and those that do not, in relation to knowledge sharing in organizations. The hypothesis is that given the nature of tacit knowledge that is subjective and difficult to encode, only ICT tools that allow dialogue are effective in sharing knowledge. Previous research has asked the question whether tacit knowledge can be transmitted using ICT tools and results have been confusing. Hence, it is proposed that the question cannot be general, but that ICT tools will be effective in sharing tacit knowledge only if they facilitate dialogue.

The instrument used in this study for measuring tacit knowledge and ICT tools for share knowledge was validated previously by Castaneda et al. (2015). The instrument used a Likert scale with five levels of response. The validation of this instrument obtained a Cronbach's alpha reliability score of 0.94 for knowledge types and 0.95 for the tools used to share knowledge.

The purpose of this instrument is twofold. On the one hand, evaluate the different ways in which knowledge is shared in organizations and, on the other, evaluate the different tools 
through which tacit and explicit knowledge is shared. The final version of the instrument has 32 items in the first part and 24 items in the second. The procedure followed for the validation of the instrument was structured in three central elements: the construction of items, the psychometric validation using the model of Rasch (1980) and the verification of subscales of the construct through the identification of the dimensions of the instrument. The instrument utilized the levels of answer: applicable, but I don " $t$ use it at all; I rarely use it; I use it fairly often; and, I use it a lot. A further category included as an alternative was "does not apply in my organization". This was included to avoid a forced answer. The scale Information and communication technology tools of this instrument is ordinal, where the distance between each response category is not identical or equal interval. In this case, the model of Rasch allows the obtaining of objective and additive measures from stochastic answers using the model for polytomous answers.

The instrument evaluated different tools for sharing knowledge, i.e. face to face tools, such as focus groups and knowledge cafes, ICT tools that facilitate dialogue, e.g. text messaging and video-conferences, and ICT tool that do not facilitate dialogue in real time, including emails. The focus of this research was tacit knowledge and the tools workers use to share knowledge.

The instrument was validated in Spanish so an English version of the same instrument was used. The validation process in English used the translation back translation procedure proposed by Brislin (1970). The steps followed were: Instrument translation from Spanish to English, consult a panel of three experts, blind back translation, verification of linguistic and cultural equivalence and a pilot study. The validation of the English version of the instrument obtained a Cronbach's alpha reliability score of 0.90 for knowledge types and 0.92 for the tools used to share knowledge.

Subsequently, the final version of the instrument was posted on the internet in an electronic format. The responses from the 217 participants were stored in a database for further analysis.

\section{Data analysis and results}

The research model contemplated the calculation of the correlations among the variables. It was used the Pearson correlation coefficient. This tool is typically used for jointly normally distributed data, this is, data that follow a bivariate normal distribution. The data were distributed along Gaussian bell-shaped curve and for each value of $\mathrm{x}$, there was a subpopulation of normally distributed values of $\mathrm{y}$.

The size of the sample $(\mathrm{N})$ was 217 . There was a positive and significant correlation, 0.91 , between tacit knowledge and ICTs that facilitate dialogue $p=0.001 ; \alpha=0.231$, but no significant correlation, 0.64 between tacit knowledge and ICTs that do not facilitate dialogue $p=0.518 ; \alpha=0.044$ (Table 1). The coefficient of determination was 0.83 . The proportion of the variance in tacit knowledge that is accounted for the ICTs that facilitate dialogue is high.

\begin{tabular}{|c|c|c|c|c|}
\hline Correlations & Tacit knowledge & $\begin{array}{l}\text { ICTs that do not } \\
\text { facilitate dialogue }\end{array}$ & $\begin{array}{c}\text { ICTs that facilitate } \\
\text { dialogue }\end{array}$ & \\
\hline \multicolumn{5}{|l|}{ Tacit Knowledge } \\
\hline Pearson's correlation coefficient & 1 & 0.044 & $0.231^{* * *}$ & \\
\hline Sig. (bilateral) & & 0.518 & 0.001 & \\
\hline $\mathrm{N}$ & 217 & 217 & 217 & $\begin{array}{r}1 \text { able } 1 . \\
\text { Correlations betwreen }\end{array}$ \\
\hline Sig. (bilateral) & 0.518 & & 0.000 & Correlations between \\
\hline $\mathrm{N}$ & 217 & 217 & 217 & types of knowledge \\
\hline Sig. (bilateral) & 0.001 & 0.000 & 0.000 & and channels for \\
\hline $\mathrm{N}$ & 217 & 217 & 217 & sharing knowledge \\
\hline
\end{tabular}


GKMC $70,8 / 9$

\section{8}

In addition, multiple linear regression was used as a way to model the relationship between tacit knowledge and the channels for sharing knowledge. The results showed that ICTs that facilitate dialogue were effective tools for sharing tacit knowledge, $p=0.006$, which was significant. In relation to B it was 0.174 (no standardized coefficient) and Beta was 0.204 (standardized coefficient). This value is understood as the degree of change in the outcome variable for every one unit of change in the predictor variable. By contrast, ICTs that do not facilitate dialogue were not suitable tools for sharing tacit knowledge, $p=0.254$, which was not significant (Table 2).

In conclusion, the data analysis supported the proposal of this research, which affirms that not all ICT-based tools facilitate the exchange of tacit knowledge, but rather those that facilitate dialogue.

\section{Discussion}

The efficiency and speed at which organizations can utilize and exploit the knowledge of employees may determine their success (Cordeiro-Nisson and Hawamdeh, 2011). Transferring tacit knowledge is a challenge because it is embedded in the person rather than in a document. In this sense, communication is a barrier to the transfer of tacit knowledge in organizations. Traditional modes of organizational communication such as the use of ICT tools to send attached files are not appropriate for transferring tacit knowledge because this knowledge is not packaged. In addition, using email to transfer tacit knowledge might risk misunderstandings or a lack of understanding.

In the present research, it was found that not all ICT technologies let tacit knowledge to be shared, but those ICT that facilitate dialogue. In terms of The Jennex and Olfman KM success model (Jennex and Olfman, 2006; Jennex, 2020), the system quality affects the knowledge management level. According to our results, some technological resources, in particular those that allow dialogue affect positively the knowledge management level, specifically the effectiveness of the shared knowledge.

In the context of franchise businesses, Cumberland and Githens (2012) found that online tools that help individuals to talk and discuss ideas may contribute to the successful exchange of tacit knowledge. This conclusion matches with the results obtained in the present study where we found that ICT tools that permit dialogue between individuals are suitable for the exchange of tacit knowledge. Oral language is the main tool for exchanging tacit knowledge. Thus, organizations should train workers in how to use language as a tool for exchanging tacit knowledge. For example, storytelling, metaphors, and analogies are efficient tools for the exchange of tacit knowledge. Lyles and Salk (1996) found that the managerial know-how acquired via tacit knowledge exchange can contribute to improved organizational performance. Finally, in words of Jennex and Olfman (2006), each individual

Table 2.

Regression coefficients

\begin{tabular}{|c|c|c|c|c|c|}
\hline & No stand & dized coefficients & $\begin{array}{c}\text { Standardized } \\
\text { coefficients }\end{array}$ & & \\
\hline Model & B & Standard error & Beta & $t$ & Sig. \\
\hline 1 (Constant) & 2.737 & 0.219 & & 12.506 & 0.000 \\
\hline ICTs that do not facilitate dialogue & -0.080 & 0.070 & -0.082 & -1.143 & 0.254 \\
\hline ICTs that facilitate dialogue & 0.174 & 0.062 & 0.204 & 2.788 & 0.006 \\
\hline
\end{tabular}

Note: Dependent variable: Tacit Knowledge 
impact should have an effect on the performance of the whole organization; in this sense, the effectiveness of exchange of tacit knowledge contributes to the creation and use of relevant organizational knowledge.

An implication for practitioners based on this study is that email should not be the preferred mode for transferring knowledge between an organization and their workers. This mode is adequate for the exchange of explicit knowledge but it has a limited capacity for transferring tacit knowledge. Thus, organizations may increase the use of audio and video tools to transfer electronically tacit knowledge. Interaction or socialization may facilitate the understanding and internalization of tacit knowledge by workers. It is recommended to study the effectiveness of other tools to share tacit knowledge, for example mobile phones. This particular tool has been successful in enhancing human capabilities (Msoffe and Lwoga, 2020).

\section{Conclusions}

In this study, it was evaluated the effectiveness of ICT tools for sharing tacit knowledge in organizations. Previous studies have reported the ineffectiveness of ICT tools for sharing tacit knowledge (Abadi et al., 2009), whereas other have suggested their effectiveness (Razmerita et al., 2014). In this study, it was obtained empirical support for ICT tools facilitating the sharing of tacit knowledge but only when they permit dialogue. It was found that ICT tools such as text messaging and video conferencing could allow the participants to share tacit knowledge, whereas other ICT tools do not facilitate tacit knowledge exchange such as emails.

From an academic perspective, the results of this study help to fill the gap in the understanding of the suitability of ICT tools for sharing tacit knowledge. From the viewpoint of practitioners, the results of this study provide insights into the redesign strategies and activities required for organizational communication and collaborative work in order to make the exchange of tacit knowledge more productive in the context of knowledge creation and application, as well as in fundamental knowledge management processes.

\section{References}

Abadi, S., Hussini, S., Sriraj, W., Thienthong, S. and Finley, G. (2009), "Knowledge sharing for pediatric pain management via web 2.0 framework", Studies in Health Technology and Informatics, Vol. 150, pp. 287-291.

Abdelrahman, M., Papamichail, K.N. and Wood-Harper, T. (2016), "To share or not to share: an exploratory review of knowledge management systems and knowledge sharing in multinational corporations", UK Academy for information systems (UKAIS) 21st Annual Conference - 2016, 11-13 April 2016, Oxford.

Autor, D., Levy, F. and Murnane, R. (2003), "The skill content of recent technological change: an empirical exploration”, The Quarterly Journal of Economics, Vol. 118 No. 4, pp. 1279-1333.

Berners-Lee, T., Hendler, J. y. and Lassila, O. (2006), “The semantic web”, Scientific American, Vol. 284 No. 5, pp. 34-43.

Castaneda, D.I. (2015), "Knowledge sharing: the role of psychological variables in leaders and collaborators", Suma Psicológica, Vol. 22 No. 1, pp. 63-69.

Castaneda, D.I. and Cuellar, S. (2020), "Knowledge sharing and innovation: a systematic review", Knowledge and Process Management, Vol. 27 No. 3, pp. 159-173. 
GKMC $70,8 / 9$

Castaneda, D.I. and Toulson, P. (2013), "The value of human resources measurement in intellectual Capital and knowledge sharing", The Electronic Journal of Knowledge Management, Vol. 11 No. 3, pp. 226-234.

Castaneda, D.I., Fernández, M. and Durán, W. (2016), "Determinants of knowledge sharing intention and knowledge sharing behavior in a public organization", Knowledge Management and E-Learning, Vol. 8 No. 2, pp. 372-386.

Castaneda, D., Manrique, L. and Cuellar, S. (2018), "Is organizational learning being absorbed by knowledge management? A systematic", Journal of Knowledge Management, Vol. 22 No. 2, pp. 299-325.

Castaneda, D.I., Pardo, C. and Toulson, P. (2015), “A Spanish knowledge sharing instrument validation”, Electronic Journal of Knowledge Management, Vol. 13 No. 1, pp. 3-12.

Cordeiro-Nisson, C. and Hawamdeh, S. (2011), "Leveraging socio-cultural situated tacit knowledge", Journal of Knowledge Management, Vol. 15 No. 1, pp. 88-103.

Crhová, Z. and Matosková, J. (2019), "The link between knowledge sharing and organizational performance: empirical evidence from Czech Republic", International Journal of Knowledge Management, Vol. 15 No. 3, pp. 1-23.

Cumberland, D. and Githens, R. (2012), "Tacit knowledge barriers in franchising: Practical solutions", Journal of Workplace Learning, Vol. 24 No. 1, pp. 48-58.

Del Giudice, M. and Della Peruta, M. (2016), “The impact of IT-based knowledge management systems on internal venturing and innovation: a structural equation modeling approach to corporate performance", Journal of Knowledge Management, Vol. 20 No. 3, pp. 484-498.

DeLone, W. and McLean, E. (1992), "Information systems success. The quest for the dependent variable", Information Systems Research, Vol. 3 No. 1, pp. 60-95.

DeLone, W. and McLean, E. (2003), "The DeLone and McLean model of information systems success: a ten year update", Journal of Management Information Systems, Vol. 19 No. 4, pp. 9-30.

Dingsoyr, T., Bjornson, F. and Shull, F. (2009), "What do we know about knowledge management? Practical implications for software engineering”, IEEE Software, Vol. 26 No. 3, pp. 100-103.

Dougherty, V. (1999), "Knowledge is about people, not databases", Industrial and Commercial Training, Vol. 31 No. 7, pp. 262-266.

Drucker, P. (1999), "Knowledge-worker productivity: the biggest challenge", California Management Review, Vol. 41 No. 2, pp. 79-92.

Duran, G. and Castaneda, D.I. (2015), "Relación entre liderazgo transformacional y transaccional con la conducta de compartir conocimiento en dos empresas de servicios", Acta Colombiana de Psicología, Vol. 18 No. 1, pp. 135-147.

Earl, M. (2001), "Knowledge management strategies: toward a taxonomy", Journal of Management Information Systems, Vol. 18 No. 1, pp. 215-233.

Eden, C. and Spender, J. (1998), Managerial and Organizational Cognition Theory, Methods and Research, Sage, London.

Falconer, L. (2006), “Organizational learning, tacit information, and e-learning: a review”, The Learning Organization, Vol. 13 No. 2, pp. 140-151.

Flanagin, A. (2002), "The elusive benefits of the technological support of knowledge management", Management Communication Quarterly, Vol. 16 No. 2, pp. 242-248.

Gibbert, M. and Krause, H. (2002), "Practice exchange in a best practice marketplace", in Davenport T. and Probst, G. (Eds), Knowledge Management Case Book: Best Practices, Publicis MCD Berlin, pp. 68-84.

Haldin-Herrgard, T. (2000), "Difficulties in diffusion of tacit knowledge in organizations", Journal of Intellectual Capital, Vol. 1 No. 4, pp. 357-365. 
Helmstadter, E. (2003), "The institutional economics of knowledge sharing. basic issues", in Helmstadter, E. (Ed.), The Economics of Knowledge Sharing. A New Institutional Approach, Edgard Elgar, Cheltenham y Northampton, M.A, pp. 11-38.

Hendriks, P. (2004), "Assessing the role of culture in knowledge sharing", In Proceedings of fifth European Conference in Organization, Knowledge, Learning and Capabilities, Innsbruck, Austria.

Hewitt, B., Walz, D. and McLead, A. (2020), "The effect of conflict and knowledge sharing on the information technology project team performance", International Journal of Knowledge Management, Vol. 16 No. 1, pp. 1-20.

Huysman, M. and De Wit, D. (2002), Knowledge Sharing in Practice, Kluwer Academics Publishers, Dordrecht, The Netherlands.

Ipe, K. and Wagner, C. (2008), "Weblogging: a study of social computing and its impact on organizations”, Decision Support Systems, Vol. 45 No. 2, pp. 242-250.

Issac, A. and Thomas, T. (2020), "Whom to appease and whom to circumvent: analyzing knowledge sharing with social networks", Global Knowledge, Memory and Communication, Vol. 69 Nos 1/2, pp. 75-93.

Jennex, M. (2020), “A re-examination and re-specification of the Jennex Olfman knowledge management success model", In Current Issues in Knowledge Management, Discovery and Transfer. Chapter 1, IGI Global.

Jennex, M. and Olfman, L. (2006), "A model of knowledge management success", International Journal of Knowledge Management, Vol. 2 No. 3, pp. 51-68.

Jennex, M., Peng, G. and Razmerita, L. (2019), "Introduction to the knowledge flows, sharing, transfer and exchange minitrack", Proceedings of the 52nd HI Conference on System Sciences.

Johanessen, J., Olaisen, J. and Olsen, B. (2001), "Mismanagement of tacit knowledge: the importance of tacit knowledge, the danger of information technology, and what to do about it", International Journal of Information Management, Vol. 21 No. 1, pp. 3-20.

Kunzel, E., Oliveira, M. and Marques, C. (2019), "Pursuing innovation through knowledge sharing", International Journal of Knowledge Management, Vol. 15 No. 1, pp. 69-84.

Lagerstrom, K. and Andersson, M. (2003), "Creating and sharing knowledge within a transactional team: the development of a global business system", Journal of World Business, Vol. 38 No. 2, pp. 84-95.

Leonard-Barton, D. (1995), Wellsprings of Knowledge, Harvard Business School Press, Boston, M.A.

Lyles, M. and Salk, J. (1996), "Knowledge acquisition from foreign parents in international joint ventures: an empirical examination in the Hungarian context", Journal of International Business Studies, Vol. 27 No. 5, pp. 877-903.

Mclever, D., Lengnick-Hall, C., Lengnick-Hall, M. and Ramachandran, I. (2013), "Understanding work and knowledge management from a knowledge-in-practice perspective", Academy of Management Review, Vol. 38 No. 4, pp. 597-620.

Meso, P. and Smith, R. (2000), "A resource based view of organizational knowledge management", Journal of Knowledge Management, Vol. 4 No. 3, pp. 224-234.

Mitri, M. (2003), “Applying tacit knowledge management techniques for performance assessment", Computers and Education, Vol. 41 No. 2, pp. 173-189.

Msoffe, G. and Lwoga, E. (2020), "Contribution of mobile phones in expanding human capabilities in selected rural districts of Tanzania. Global knowledge", Memory and Communication, Vol. 68 Nos 6/7, pp. 491-503.

Nakano, D., Muniz, J. and Dias, E. (2013), "Engaging environments: tacit knowledge sharing on the shop floor", Journal of Knowledge Management, Vol. 17 No. 2, pp. 290-306.

Ngulube, P. (2019), "Mapping methodological issues in knowledge management research 2009-2014", International Journal of Knowledge Management, Vol. 15 No. 1, pp. 85-100. 
GKMC $70,8 / 9$

\section{2}

Nonaka, I. (2007), “The knowledge creating company", Harvard Business Review, Vol. 85 Nos 7/8, pp. $162-171$.

Nonaka, I. and Takeuchi, H. (1995), The Knowledge-Creating Company, Oxford University Press, New York, NY.

Oyemomi, O., Neaga, L. and Alkhuraiji, A. (2016), "How knowledge sharing and business process contribute to organizational performance: Using the fs QCA approach", Journal of Business Research, Vol. 69 No. 11, pp. 5222-5227.

Panahi, S., Watson, J. and Partridge, H. (2013), "Towards tacit knowledge sharing over social web tools", Journal of Knowledge Management, Vol. 17 No. 3, pp. 379-393.

Panahi, S., Watson, J. and Partridge, H. (2016), "Conceptualizing social media support for tacit knowledge sharing: physicians' perspectives and experiences", Journal of Knowledge Management, Vol. 20 No. 2, pp. 344-363.

Polanyi, M. (1958), Personal Knowledge: Towards a Post-Critical Philosophy, University of Chicago Press, Chicago.

Rasch, G. (1980), Probabilistic Models for Some Intelligence and Attainment Tests, University Press, Chicago.

Razmerita, L., Kirchner, K. and Nabeth, T. (2014), "Social media in organizations: leveraging personal and collective knowledge processes", Journal of Organizational Computing and Electronic Commerce, Vol. 24 No. 1, pp. 74-93.

Razmerita, L., Kirchner, K. and Nielsen, P. (2016), "What factors influence knowledge sharing in organizations? A social dilemma perspective of social media communication", Journal of Knowledge Management, Vol. 20 No. 6, pp. 1225-1246.

Reamy, T. (2002), "Imparting knowledge through storytelling. Part 1 \& 2", KM World, Vol. 11 No. 6.

Richter, S., Waizenegger, L., Steinhueger, M. and Richter, A. (2019), "Knowledge management in the dark: the role of the shadow IT in practices in manufacturing", International Journal of Knowledge Management, Vol. 15 No. 2, pp. 1-19.

Rutten, W., Blass-Franken, J. and Martin, H. (2016), "The impact of (low) trust on knowledge sharing”, Journal of Knowledge Management, Vol. 20 No. 2, pp. 199-214.

Salleh, K., Chong, S., Ahmad, S. and Ikhsan, S. (2013), "The extent of influence of learning factors on tacit knowledge sharing among public sector accountants", VINE, Vol. 43 No. 4, pp. $424-441$.

Scarbrough, H. and Carter, C. (2000), Investigating Knowledge Management, CIPD, London.

Serenko, A. y. and Bontis, N. (2016), "Negociate, reciprocate, or cooperate? The impact of exchange modes on inter-employee knowledge sharing", Journal of Knowledge Management, Vol. 20 No. 4, pp. 687-712.

Smuts, H., Kotze, P., Van der Merwe, A. and Loock, M. (2017), "Framework for managing shared knowledge in an information systems outsourcing context", International Journal of Knowledge Management, Vol. 13 No. 4, pp. 1-30.

Spraggon, M. and Bodolica, V. (2017), "Collective tacit knowledge generation through play", Management Decision, Vol. 55 No. 1, pp. 119-135.

Steward, M. (2008), "Intraorganizational knowledge sharing among key account salespeople: the impact on buyer satisfaction”, Marketing Management Journal, Vol. 18 No. 2, pp. 65-75.

Suppiah, V. and Singh-Sandhu, M. (2011), "Organizational culturés influence on tacit knowledge sharing behavior”, Journal of Knowledge Management, Vol. 15 No. 3, pp. 462-477.

Takpuie, D. and Tanner, M. (2016), "Investigating the characteristics needed by scrum team members to successfully transfer tacit knowledge during agile software projects", The Electronic Journal Information System Evaluation, Vol. 19 No. 1, pp. 36-54.

van den Hooff, B. and Huysman, M. (2009), "Managing knowledge sharing: emerging and engineering approaches", Information and Management, Vol. 46 No. 1, pp. 1-8. 
Villamizar, M. and Castaneda, D.I. (2014), "Relation between organizational climate and its dimensions and knowledge sharing behavior among knowledge workers", International Journal of Psychological Research, Vol. 7 No. 2, pp. 64-75.

Wah, C., Menkhoff, T., Low, B., and Evers, H. (2005), "Theorizing, measurement and predicting knowledge sharing behavior in organizations", A social capital approach. Proceedings of the 38th Hawai Internacional Conference on System Sciences.

Wang, S. and Noe, R. (2010), "Knowledge sharing: a review and directions for future research", Human Resource Management Review, Vol. 20 No. 2, pp. 115-131.

\section{Corresponding author}

Delio Ignacio Castaneda can be contacted at: delio.castaneda@javeriana.edu.co

For instructions on how to order reprints of this article, please visit our website: www.emeraldgrouppublishing.com/licensing/reprints.htm Or contact us for further details: permissions@emeraldinsight.com 